\title{
Effect of agro-input management practices on yield of linseed (Linum usitatissimum L.) under vertisols of Chhattisgarh, India
}

\author{
Rajkamal Patel $^{1 *}$, Sanjay K. Dwivedi ${ }^{1}$ and R. K. Patel ${ }^{2}$ \\ ${ }^{1}$ Department of Agronomy, Indira Gandhi KrishiVishwavidyalaya, Raipur (Chhattisgarh), INDIA \\ ${ }^{2}$ Department of Agriculture, Government of Chhattisgarh (Chahattisgarh), INDIA \\ *Corresponding author. E-mail: raazpate124@gmail.com \\ Received: July 22, 2016; Revised received: February 16, 2017; Accepted: May 10, 2017
}

\begin{abstract}
A field experiment was conducted to study the effect of agro-input management practices on yield of linseed (Linum usitatissimum L.) at the Instructional cum Research Farm, Indira Gandhi Krishi Vishwavidyalaya, Raipur, (C.G.) during Rabi 2015-16. Different agro input management practices had significant $(P=0.05)$ effect on growth, yield attributes and yield of linseed. However, seed rates did not give significant influence on seed yield. Whereas, application of RDF + FYM placement in rows @ 5 t ha-1 (N3) recorded significantly $(P=0.05)$ higher growth parameters viz. plant height $(88.44 \mathrm{~cm})$, primary branches plant-1 (3.83), secondary branches plant-1 (23.39), dry matter accumulation (6.76 g plant-1) and yield attributes viz. capsules plant-1 (30.86), seeds capsule-1 (7.63), seeds plant-1 (235.32), seed yield (2100 kg ha-1) and stover yield (4885 kg ha-1). In case of foliar spray, application of $2 \%$ urea at 15, 40,65 and 90 DAS (F3) gave significantly higher growth parameters viz. plant height $(88.37 \mathrm{~cm})$, primary branches plant-1(3.82), secondary branches plant ${ }^{-1}(23.68)$, dry matter accumulation $(6.59 \mathrm{~g}$ plant $^{-1}$ ) and yield attributes viz. capsules plant ${ }^{-1}(31.74)$, seeds capsule ${ }^{-1}(7.63)$, seeds plant ${ }^{-1}(241.38)$, seed yield $\left(2089 \mathrm{~kg} \mathrm{ha}^{-1}\right)$ and stover yield $\left(4772 \mathrm{~kg} \mathrm{ha}^{-1}\right)$. Interaction among seed rate $30 \mathrm{~kg} \mathrm{ha}^{-1}\left(\mathrm{~S}_{2}\right)$ X RDF 60:30:30 N: P: K $\mathrm{kg} \mathrm{ha}^{-1}\left(\mathrm{~N}_{1}\right)$ with foliar application of $2 \%$ urea at 15, 40, 65 and 90 DAS $\left(F_{3}\right)\left(S_{2} X N_{1} X F_{3}\right)$ recorded the highest benefit-cost ratio (4.39). Line placement of FYM was better than broadcasting in terms of seed yield; and foliar application of urea was economical than Nitrobenzene.
\end{abstract}

Keywords: Economics, FYM, linseed, Yield attributes, Yield

\section{INTRODUCTION}

Linseed (Linumusitatissimum L.) is highly nutritious, unique (best herbal source of omega-3 fatty acids) and emerging among oilseeds for its technical grade vegetable oil and good quality fibre producing ability. At present, the demand and supply of edible oil is 18.94 and 10.08 million tons, respectively. The gap in demand and supply is about $47 \%$ i.e. 8.86 million tons being filled by import of edible oil (Anonymous, 2015). ISOR (2015) has projected the demand for the year 2020 and 2050 is 14.57 and $24.10 \mathrm{~kg}_{\text {year }}{ }^{-1}$ respectively. Chhattisgarh is one of the important linseed growing state of India, where it is cultivated in about 0.026 million hectare area with a production of 0.011 million tones but its productivity is low in Chhattisgarh (423 $\mathrm{kg} \mathrm{ha}^{-1}$ ) and national (498 $\mathrm{kg} \mathrm{ha}^{-1}$ ) compared to global (877 kg ha ${ }^{-1}$ ) productivity (Anonymous, 2015). Chhattisgarh having third highest yield gap between improved technology and farmer's practice in irrigated condition is found after Uttar Pradesh and Himachal Pradesh (Singh et al., 2015). The major reason for low productivity of linseed may be due to adoption of primitive sowing method like Utera and farmers having poor knowledge with regards to INM and perpetual scarcity of basic agro-inputs like improved seed, fertilizers etc. Among the agro-techniques, judicious application of seed rates, nutrients, particularly the nitrogen, phosphorus and potash play the important role for increasing linseed productivity (Singh et al., 2013). There is a need to improve nutrient supply system in terms of integrated nutrient management involving the use of chemical fertilizers in conjunction with foliar application of nutrients to the plants has been successfully used in correction of nutrient deficiency, and quickly counter a mineral unbalance that would inhibit plant metabolism. Nitrobenzene is a combination of nitrogen and plants growth regulators that act as a plant energizer, flowering stimulant and yield booster (Aziz and Miah, 2009). Therefore, it is necessary to quantify the judicious agro input for optimization of linseed (L.usitatissimum L.) productivity with sustainable manner.

\section{MATERIALS AND METHODS}

Study area: The field experiment was conducted during Rabi season of 2015-16 at the Instructional cum Research Farm, Indira Gandhi Krishi Vishwavidyalaya, Raipur $\left(21^{\circ} 4^{\prime} \mathrm{N}\right.$ latitude, $81^{\circ} 35^{\prime} \mathrm{E}$ longitude and 


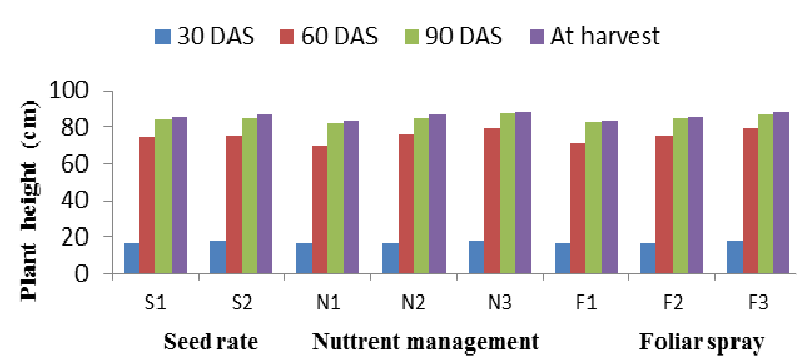

Fig. 1. Plant height $(\mathrm{cm})$ of linseed as influenced by seed rate, nutrient management and foliar spray.

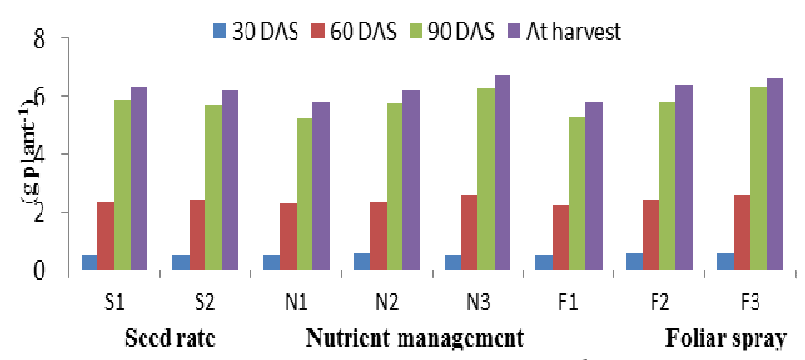

Fig. 2. Dry matter accumulation ( $g$ plant $\left.{ }^{-1}\right)$ of linseed as influenced by seed rate, nutrient management and foliar spray.

290.20 meter above mean sea level) under Chhattisgarh plains (Agro climatic zones of India). The soil was clayey in texture having $0.50 \%$ organic carbon, $6.68 \mathrm{pH}, 0.18$ Electrical Conductivity (EC) and had $226 \mathrm{~kg} \mathrm{ha}^{-1}$ available $\mathrm{N}, 12.64 \mathrm{~kg} \mathrm{ha}^{-1}$ available $\mathrm{P}$ and $367 \mathrm{~kg} \mathrm{ha}^{-1}$ available K. During the investigation, cumulative rainfall $16.1 \mathrm{~mm}$ was received, while average minimum and maximum temperature, morning and evening relative humidity, evaporation and sunshine viz. $15.5{ }^{\circ} \mathrm{C}, 30.4{ }^{0} \mathrm{C}, 83.4 \%, 36.8 \%, 3.3 \mathrm{~mm}$ and 6.0 hours, respectively.

Treatments detail: The experiment was laid out in factorial randomized block design with three replications and eighteen treatments. The treatment consisted of two seed rate viz. $25 \mathrm{~kg} \mathrm{ha}^{-1}\left(\mathrm{~S}_{1}\right), 30 \mathrm{~kg} \mathrm{ha}^{-1}\left(\mathrm{~S}_{2}\right)$, three nutrient managements viz. RDF (Recommended dose of fertilizers) 60:30:30 N, $\mathrm{P}_{2} \mathrm{O}_{5} \& \mathrm{~K}_{2} \mathrm{O} \mathrm{kg} \mathrm{ha}{ }^{-1}$ $\left(\mathrm{N}_{1}\right)$, RDF + Incorporation of FYM (Farm yard manure) @ $5 \mathrm{t} \mathrm{ha}^{-1}\left(\mathrm{~N}_{2}\right)$, RDF + FYM placement in rows (a $5 \mathrm{t} \mathrm{ha}^{-1}\left(\mathrm{~N}_{3}\right)$ and three foliar spray, water spray at 15, 40, 65 and 90 DAS $\left(\mathrm{F}_{1}\right)$, foliar spray of Nitrobenzene @ $0.06 \%$ at 15, 40, 65 and 90 DAS (days after sowing) $\left(\mathrm{F}_{2}\right)$ and foliar spray of $2 \%$ urea at 15, 40, 65 and 90 DAS $\left(\mathrm{F}_{3}\right)$.

Crop management: Linseed (cv: $R L C$-92) was planted on $22^{\text {nd }}$ November, 2015 and were harvested on $12^{\text {th }}$ March, 2016. All the recommended agronomic management practices were followed except for the treatments.

Statistical analysis: Standard procedure was adopted for recording the data on various growth and yield parameters. Data collected were statistically analyses by the procedure suggested by Gomez and Gomez (1984).

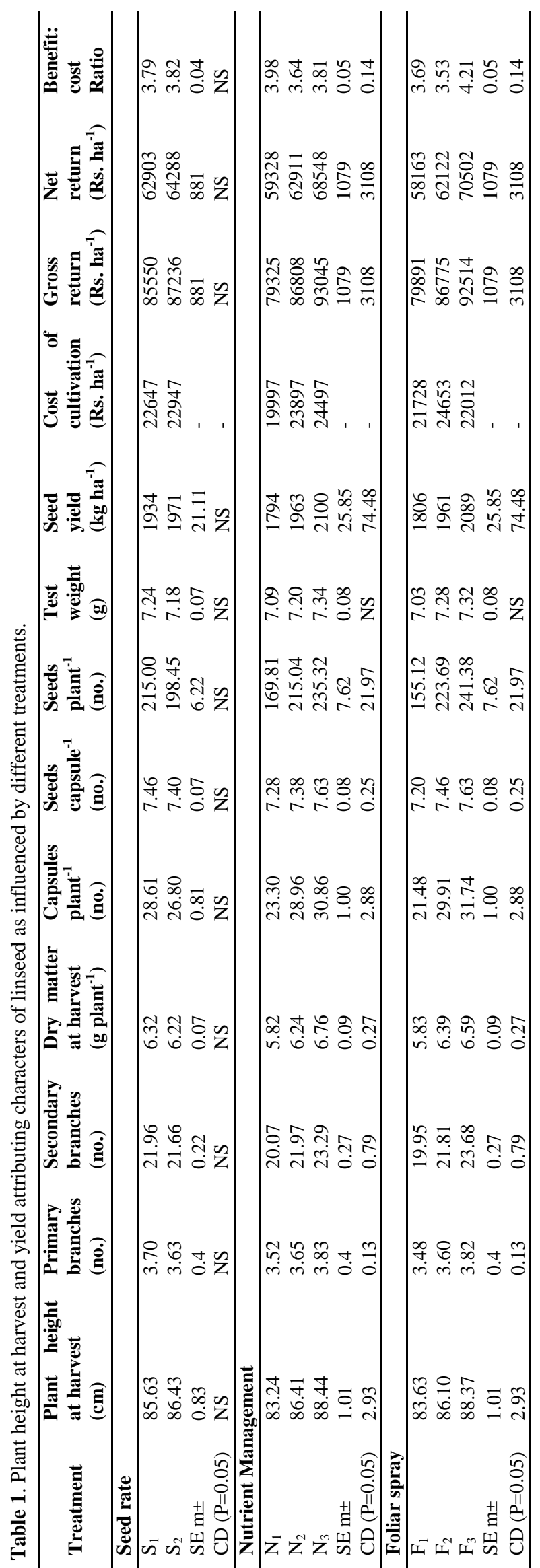


Rajkamal Patel et al. / J. Appl. \& Nat. Sci. 9 (2): 1072 - 1076 (2017)

Table 2. Correlation coefficients of seed yield of linseed crop with respect to growth parameter and yield attributes.

\begin{tabular}{|c|c|c|c|c|c|c|c|c|c|}
\hline & SY & $\mathbf{P H}$ & NPB & NSB & DMAP & NCPP & NSPC & NSPP & TSW \\
\hline SY & $1.000 * *$ & $0.998 * *$ & $0.942 * *$ & $0.982 * *$ & $0.971 * *$ & $0.933 * *$ & $0.950 * *$ & $0.930 * *$ & $0.927 * *$ \\
\hline PH & & $1.000 * *$ & $0.932 * *$ & $0.977 * *$ & $0.958 * *$ & $0.923 * *$ & $0.933 * *$ & $0.921 * *$ & $0.909 * *$ \\
\hline NPB & & & $1.000 * *$ & $0.970 * *$ & $0.936^{* *}$ & $0.903 * *$ & $0.962 * *$ & $0.898 * *$ & $0.902 * *$ \\
\hline NSB & & & & $1.000 * *$ & $0.963 * *$ & $0.962 * *$ & $0.970 * *$ & $0.958 * *$ & $0.944 * *$ \\
\hline DMAP & & & & & $1.000 * *$ & $0.953 * *$ & $0.970 * *$ & $0.952 * *$ & $0.974 * *$ \\
\hline NCPP & & & & & & $1.000 * *$ & $0.952 * *$ & $0.999 * *$ & $0.985 * *$ \\
\hline NSPC & & & & & & & $1.000 * *$ & $0.946 * *$ & $0.971 * *$ \\
\hline NSPP & & & & & & & & $1.000 * *$ & $0.983 * *$ \\
\hline TSW & & & & & & & & & $1.000 * *$ \\
\hline
\end{tabular}

Where: $\mathrm{SY}=$ Seed yield; $\mathrm{PH}=$ Plant height; $\mathrm{NPB}=$ No. of Primary branches per plant; NSB= No. of secondary branches per plant; $\mathrm{DMAP}=$ Dry matter accumulation per plant; NCPP $=$ No. of capsules per plant; NSPC $=$ No. of seeds per capsules; NSPP= No. of seeds per plant; TSW= Thousand seed weight $(\mathrm{g}), *, * *$ indicates significant at $5 \%$ and $1 \%$ probability level respectively

\section{RESULTS AND DISCUSSION}

Growth, yield attributing characters and yield of linseed: The seed yield, ultimate result of various interacting growth, development and yield contributing character. The data shown in Table 1 and Fig. 1 and Fig. 2 revealed that growth, yield attributing character and yield were significantly $(\mathrm{P}=0.05)$ affected due to nutrient management and foliar spray. Between seed rates, no significant difference was observed on growth, and yield of linseed. Among nutrient management, the application of recommended dose of fertilizer (RDF) + FYM placement in rows @ $5 \mathrm{t} \mathrm{ha}^{-1}\left(\mathrm{~N}_{3}\right)$ gave significantly plant height $(88.44 \mathrm{~cm})$, primary branches plant ${ }^{-1}$ (3.83), secondary branch plant $^{-1}$ (23.29), dry matter accumulation g plant ${ }^{-1}$ (6.76), capsules plant ${ }^{-1}(30.86)$, seeds capsule ${ }^{-1}(7.63)$, seeds plant ${ }^{1}$ (235.32), test weight (7.34) and seed yield (2100 kg $\left.\mathrm{ha}^{-1}\right)$. However, plant height at harvest, capsules plant ${ }^{1}$, seeds capsule ${ }^{-1}$ and seeds plant ${ }^{-1}$ was found at par with the same treatment. The lowest seed yield was recorded with application of RDF $\left(1794 \mathrm{~kg} \mathrm{ha}^{-1}\right)$. It is possible due to the application of RDF + FYM placement in rows@ $5 \mathrm{t} \mathrm{ha}^{-1}$ due to that NPK application along with FYM placement with rows, application of FYM to linseed improving the overall fertility status of the soil, vigorous plant growth might have produced more photosynthetic. Efficient partitioning of accumulated photosynthesis, enhanced yield attributes which ultimately positive reflection in the seed yield. Similar observations were noted by Delesa and Choferie (2015) in linseed (Linumusitatissimum L.) crop. The similar result has been reported by Khare et al. (1996) and revealed that the increment in yield attributing characters of linseed with the application of major nutrient and secondary nutrient (S). In case of the foliar spray, of nitrobenzene is a combination of nitrogen and plants growth regulators that act as a plant energizer, flowering stimulant and yield booster (Aziz and Miah, 2009). Nitrobenzene produce best result in combination with plants growth regulators, which have capacity to increase to flowering in plants and also prevent flower shedding due to more number of flower, it in- crease the yield by considerable ratio with better quality. The application of $2 \%$ urea at $15,40,65$ and 90 DAS $\left(\mathrm{F}_{3}\right)$ recorded significantly highest plant height $(88.37 \mathrm{~cm})$, primary branches plant ${ }^{-1}(3.82)$, secondary branch plant ${ }^{-1}$ (23.68), dry matter accumulation $\mathrm{g}$ plant ${ }^{-1}$ (6.59), capsules plant ${ }^{-1}$ (31.74), seeds capsule ${ }^{-1}$ (7.63), seeds plant ${ }^{-1}$ (241.38), test weight (7.32) andseed yield $\left(2089 \mathrm{~kg} \mathrm{ha}^{-1}\right)$. Whereas, application of water spray $\left(\mathrm{F}_{1}\right)$ gave the lowest seed yield $(1806 \mathrm{~kg}$ ha ${ }^{1}$ ). However, plant height at harvest, dry matter accumulation at harvest, capsules plant ${ }^{-1}$, seeds capsule ${ }^{-1}$ and seeds plant ${ }^{-1}$ was found at par with the same treatment. Physiological activities like chlorophyll content and total photosynthetic pigments in leaves were significantly $(\mathrm{P}=0.05)$ increased with increasing nitrogen level. Foliar nutrient application of urea remarkably improved growth traits of linseed (Linumusitatissimum L.) crop and similar results was also obtained by ElKady et al. (2010) in sunflower (Helianthusannus L.) crop at Egypt.

Correlation analysis: The correlation coefficients of seed yield with plant height $(0.998)$, number of primary branches plant ${ }^{-1}(0.942)$, number of secondary branches plant ${ }^{-1}(0.982)$, dry matter accumulation plant ${ }^{-1}(0.971)$, capsules plant $^{-1}(0.933)$, seeds capsule ${ }^{-1}$ $(0.950)$, seeds plant ${ }^{-1}(0.930)$ and 1000 seeds weight $(0.927)$ by linseed were significant at $1 \%$ level of significance (Table 2). All these characters, showed positive associations with seed yield. These findings are similar to Mirshekari et al. (2012) which was found that the correlation coefficient of seed yield was highly significant and positive correlated with plant height, number of primary branchesplant ${ }^{-1}$, capsules plant $^{-1}$, seeds capsule ${ }^{-1}$ and thousand seed weight in linseed $(L$. usitatissimum L.) crop at Iran.

Interaction analysis of seed yield: Interaction effects of seed rates, nutrient managements and foliar spray on seed yield were found significant and data are presented in Table 3. The interaction of application of seed rate $30 \mathrm{~kg} \mathrm{ha}^{-1}\left(\mathrm{~S}_{2}\right), \mathrm{RDF}+\mathrm{FYM}$ placement in rows@ $5 \mathrm{t} \mathrm{ha}^{-1}\left(\mathrm{~N}_{3}\right)$ with foliar application of $2 \%$ urea at $15,40,65$ and 90 DAS $\left(\mathrm{F}_{3}\right)$ recorded significantly $(\mathrm{P}=0.05)$ highest seedyield $\left(2344 \mathrm{~kg} \mathrm{ha}^{-1}\right)$ than 
Table 3. Interaction effect of seed rate, nutrients and foliar spray on seed yield of linseed.

\begin{tabular}{|c|c|c|c|c|c|}
\hline \multirow{3}{*}{\multicolumn{2}{|c|}{ Treatment }} & \multirow{2}{*}{\multicolumn{4}{|c|}{$\frac{\text { Seed yield }\left(\mathrm{kg} \mathrm{ha}^{-1}\right)}{\text { Foliar spray }}$}} \\
\hline & & & & & \\
\hline & & F1 & \multirow[t]{2}{*}{ F2 } & \multirow[t]{2}{*}{ F3 } & \multirow[t]{2}{*}{ Mean } \\
\hline \multicolumn{3}{|c|}{ Seed rate $X$ Nutrient management } & & & \\
\hline $\mathrm{S}_{1} \mathrm{X} \mathrm{N} \mathrm{N}_{1}$ & $25 \mathrm{~kg} \mathrm{ha}^{-1}$ X RDF (60:30:30 N:P:K kg ha $\left.{ }^{-1}\right)$ & 1533 & 1881 & 1838 & 1751 \\
\hline $\mathrm{S}_{1} \mathrm{X} \mathrm{N} \mathrm{N}_{2}$ & $25 \mathrm{~kg} \mathrm{ha}^{-1} \mathrm{X}$ RDF + Incorporation of FYM & 1880 & 1927 & 2035 & 1948 \\
\hline $\mathrm{S}_{1} \mathrm{X} \mathrm{N}_{3}$ & $25 \mathrm{~kg} \mathrm{ha}^{-1} \mathrm{X}$ RDF + FYM placement in rows & 1910 & 2091 & 2306 & 2102 \\
\hline $\mathrm{S}_{2} \mathrm{X} \mathrm{N} \mathrm{N}_{1}$ & $30 \mathrm{~kg} \mathrm{ha}^{-1}$ X RDF (60:30:30 N:P:K kg ha-1) & 1858 & 1731 & 1923 & 1837 \\
\hline $\mathrm{S}_{2} \mathrm{X} \mathrm{N}_{2}$ & $30 \mathrm{~kg} \mathrm{ha}^{-1} \mathrm{X} \mathrm{RDF}+$ Incorporation of FYM & 1820 & 2028 & 2089 & 1979 \\
\hline $\mathrm{S}_{2} \mathrm{X} \mathrm{N}_{3}$ & $30 \mathrm{~kg} \mathrm{ha}^{-1} \mathrm{X}$ RDF + FYM placement in rows & 1836 & 2107 & 2344 & 2096 \\
\hline Mean & & 1806 & 1961 & 2089 & \\
\hline $\mathrm{SE} \mathrm{m} \pm$ & & \multicolumn{4}{|c|}{63.33} \\
\hline $\mathrm{CD}(\mathrm{P}=0$ & & \multicolumn{4}{|c|}{182.44} \\
\hline
\end{tabular}

Table 4. Interaction effect of seed rate, nutrients and foliar spray on benefit: cost ratio of linseed.

\begin{tabular}{|c|c|c|c|c|c|}
\hline \multirow{3}{*}{\multicolumn{2}{|c|}{ Treatment }} & \multicolumn{4}{|c|}{ Benefit: cost ratio } \\
\hline & & \multicolumn{4}{|c|}{ Foliar spray } \\
\hline & & F1 & F2 & F3 & Mean \\
\hline \multicolumn{6}{|c|}{ Seed rate $\mathrm{X}$ Nutrient management } \\
\hline $\mathrm{S}_{1} \mathrm{X} \mathrm{N} \mathrm{N}_{1}$ & $25 \mathrm{~kg} \mathrm{ha}^{-1}$ X RDF (60:30:30 N:P:K kg ha $\left.{ }^{-1}\right)$ & 3.62 & 3.82 & 4.27 & 3.91 \\
\hline $\mathrm{S}_{1} \mathrm{X} \mathrm{N}_{2}$ & $25 \mathrm{~kg} \mathrm{ha}^{-1} \mathrm{X}$ RDF + Incorporation of FYM & 3.66 & 3.33 & 3.92 & 3.64 \\
\hline $\mathrm{S}_{1} \times \mathrm{N}_{3}$ & $25 \mathrm{~kg} \mathrm{ha}^{-1} \mathrm{X}$ RDF $+\mathrm{FYM}$ placement in rows & 3.63 & 3.53 & 4.34 & 3.83 \\
\hline $\mathrm{S}_{2} \times \mathrm{N}_{1}$ & $30 \mathrm{~kg} \mathrm{ha}^{-1} X$ RDF (60:30:30 N:P:K kg ha $\left.{ }^{-1}\right)$ & 4.29 & 3.48 & 4.39 & 4.06 \\
\hline $\mathrm{S}_{2} \mathrm{X} \mathrm{N} \mathrm{N}_{2}$ & $30 \mathrm{~kg} \mathrm{ha}^{-1} \mathrm{X}$ RDF + Incorporation of FYM & 3.51 & 3.46 & 3.97 & 3.65 \\
\hline $\mathrm{S}_{2} \times \mathrm{N}_{3}$ & $30 \mathrm{~kg} \mathrm{ha}^{-1} \mathrm{X}$ RDF $+\mathrm{FYM}$ placement in rows & 3.45 & 3.53 & 4.36 & 3.78 \\
\hline Mean & & 3.69 & 3.53 & 4.21 & \\
\hline SE $\mathrm{m} \pm$ & & \multicolumn{4}{|c|}{0.12} \\
\hline $\mathrm{CD}(\mathrm{P}=0$ & & \multicolumn{4}{|c|}{0.35} \\
\hline
\end{tabular}

other treatments. But it was found at par to interaction between applications of seed rate $25 \mathrm{~kg} \mathrm{ha}^{-1}\left(\mathrm{~S}_{1}\right) \mathrm{X}$ application of RDF + FYM placement in rows @ $5 \mathrm{t}$ ha $^{-1}\left(\mathrm{~N}_{3}\right) \mathrm{X}$ foliar application of $2 \%$ urea at 15, 40, 65 and $90 \mathrm{DAS}\left(\mathrm{F}_{3}\right)\left(\mathrm{S}_{1} \mathrm{XN}_{3} \mathrm{X} \mathrm{F}_{3}\right)$. The lowest seedyield $\left(1533 \mathrm{~kg} \mathrm{ha}^{-1}\right)$ was noted underapplications of seed rate $25 \mathrm{~kg} \mathrm{ha}^{-1}\left(\mathrm{~S}_{1}\right)$ XRDF 60:30:30 N:P:K kg ha ${ }^{-1}\left(\mathrm{~N}_{1}\right)$ $\mathrm{X}$ water spray $\left(\mathrm{F}_{1}\right)\left(\mathrm{S}_{1} \mathrm{X} \mathrm{N}_{1} \mathrm{X} \mathrm{F}_{1}\right)$.

Economics of linseed: Between seed rates, use of 30 $\mathrm{kg} \mathrm{ha}^{-1}\left(\mathrm{~S}_{2}\right)$ had more cost $\left(\square 22947 \mathrm{ha}^{-1}\right)$ towards linseed production than seed rate of $25 \mathrm{~kg} \mathrm{ha}^{-1}\left(\mathrm{~S}_{1}\right)$ ( $\square$ $22647 \mathrm{ha}^{-1}$ ), this might be due to higher price with higher quantity of seed cost hence, higher cost of cultivation was observed with the application of $30 \mathrm{~kg} \mathrm{ha}^{-1}$ seed rate. Among nutrient management, RDF + FYM placement in rows @ $5 \mathrm{t} \mathrm{ha}^{-1}\left(\mathrm{~N}_{3}\right)$ incurred more cost $\left(\square 24497 \mathrm{ha}^{-1}\right.$ ) towards linseed production followed by $\mathrm{RDF}+$ incorporation of FYM @ $5 \mathrm{t} \mathrm{ha}^{-1}\left(\mathrm{~N}_{2}\right)(\square 23897$ $\left.\mathrm{ha}^{-1}\right)$. It is because of higher cost of FYM and labour imposed on placement in rows. The lower cost on production ( $\square 19997 \mathrm{ha}^{-1}$ ) was recorded with the application of in $\operatorname{RDF}\left(\mathrm{N}_{1}\right)$ treatment. The treatment RDF + FYM placement in rows $\left(\mathrm{N}_{3}\right)$ gave the highest gross return ( $\left.\square 93045 \mathrm{ha}^{-1}\right)$, net return $\left(\square 68548 \mathrm{ha}^{-1}\right)$ but the application of RDF 60:30:30 N: P: K kg ha-1 $\left(\mathrm{N}_{1}\right)$ incurred low cost of cultivation ( $\square 19997 \mathrm{ha}^{-1}$ ), which have low gross return ( $\square 79325 \mathrm{ha}^{-1}$ ), net return ( $\square$ $59328 \mathrm{ha}^{-1}$ ) but they gave high benefit-cost ratio (3.98). It is because due to no cost of FYM and labour imposed on it. Among the foliar spray, application of 2
$\%$ urea at 15, 40, 65 and 90 DAS $\left(\mathrm{F}_{3}\right)$ gave the highest gross return $\left(\square 92514 \mathrm{ha}^{-1}\right)$, net return $\left(\square 70502 \mathrm{ha}^{-1}\right)$ and highest benefit-cost ratio (4.21). This was followed by foliar application of $0.06 \%$ Nitrobenzene at $15,40,65$ and 90 DAS $\left(\mathrm{F}_{2}\right)$, gross return $\left(\square 86775\right.$ ha $^{-}$ ${ }^{1}$ ) and net return ( $\square 62122 \mathrm{ha}^{-1}$ ), but application of water spray $\left(F_{1}\right)$ which had lowest gross return( $\square$ $79891 \mathrm{ha}^{-1}$ ) and net return ( $\square 58163 \mathrm{ha}^{-1}$ ) and higher benefit-cost ratio (3.69) compared to foliar spray of nitrobenzene (3.53) due to high cost of nitrobenzene as compared to water spray.

Interaction of B: C Ratio: Interaction effects of seed rate, nutrient managements and foliar applicationon benefit-cost ratio were found significant $(\mathrm{P}=0.05)$. The interaction among seed rate $30 \mathrm{~kg} \mathrm{ha}^{-1}\left(\mathrm{~S}_{2}\right)$ XRDF 60:30:30 N: P: K kg ha ${ }^{-1}\left(\mathrm{~N}_{1}\right) \mathrm{X}$ application of $2 \%$ urea at 15, 40, 65 and 90 DAS $\left(\mathrm{F}_{3}\right)$ recorded significantly highest benefit-cost ratio (4.39) $\left(\mathrm{S}_{2} \mathrm{X} \mathrm{N} \mathrm{N}_{1} \mathrm{X}_{3}\right)$ than other interactions.

\section{Conclusion}

Based on the above findings it was concluded that the application of RDF + FYM placement in rows @ $5 \mathrm{t}$ ha $^{-1}\left(\mathrm{~N}_{3}\right)$ recorded higher value of important growth, yield attributes and seed yield of linseed $(2100 \mathrm{~kg} \mathrm{ha}$ $\left.{ }^{1}\right)$. Among different foliar spray, application of $2 \%$ urea at 15, 40, 65 and 90 DAS $\left(\mathrm{F}_{3}\right)$ was produced higher value of important growth, yield attributes and seed yield of linseed $\left(2089 \mathrm{~kg} \mathrm{ha}^{-1}\right)$ as well as accrued handsome B: C ratio (4.21). Seed yield of linseed was 
recorded maximum (2344 $\mathrm{kg} \mathrm{ha}^{-1}$ ) when crop was sown with higher seed rate i.e. $30 \mathrm{~kg} \mathrm{ha}^{-1}$ and applied with RDF + FYM placement in rows combined with foliar application of $2 \%$ urea. In terms of economics the maximum Benefit: Cost ratio (4.39) was obtained with interaction among seed rate $30 \mathrm{~kg} \mathrm{ha}^{-1}\left(\mathrm{~S}_{2}\right) \mathrm{X}$ RDF 60:30:30 N: P: K kg ha ${ }^{-1}\left(\mathrm{~N}_{1}\right) \mathrm{X}$ application of 2 $\%$ urea at 15, 40, 65 and 90 DAS $\left(\mathrm{F}_{3}\right)$ gave significantly highest benefit-cost ratio than others $\left(\mathrm{S}_{2} \mathrm{X} \mathrm{N} \mathrm{N}_{1} \mathrm{X}\right.$ $\mathrm{F}_{3}$ ). Line placement of FYM was better than broadcasting in term of seed yield; and foliar application of urea was better than Nitrobenzene in terms of seed yield and net profit.

\section{REFERENCES}

Anonymous (2015). Status paper on oilseeds. Department of Agriculture and Cooperation, Ministry of Agriculture, Govt. of India. pp 104-105.

Aziz, M.A. and Miah, M.A.M. (2009). Effect of the "flora" on the growth and yield of wet land rice. Journal of Agricultural Rural Development, 7: 9-13

Delesa, A. and Choferie, A. (2015). Response of linseed (LinumusitatissimumL.) to seed rates and seeding methods in South-Eastern highlands of Ethiopia. Journal of Biology, Agriculture and Healthcare, 5(13)

El-Kady, F. A., Awad, M. M. and Osman, E. B. A. (2010).
Effect of nitrogen fertilizer rates and foliar fertilization on growth, yield and yield components of sunflower. Journal of Plant Production, 1(3): 451-459

Gomez, K. A. and Gomez, A.A. (1984). Statistical procedure for Agriculture Research. A Willey- Inter-Science Publication, John Willey and Sons, New York. Pp.108-127

ISOR (2015). Extended Summaries: National Seminar on Strategic interventions to enhance oilseeds production in India. February 19-21, 2015. Indian Society of Oilseeds Research, Hyderabad.

Khare, J. P., Sharma, R. S. and Sony, N. K. (1996). Effect of sulphur and antitranspirants on yield attributes, yield and nutrient uptake in rainfed linseed. Journal of Oilseed Research, 13(2): 182-186

Mirshekari, M., Amrity, R., Nezhad, H. I., Noori, S. A. S. and Zandvakili, O. R. (2012). Effect of planting date and water deficit on quantitative and qualitative traits of flax seed. American Eurasian Journal of Agricultural and Environment Science, 12(7): 901-913

Singh, D. N., Bohra, J. S. and Singh, J. K. (2013).Influence of NPK, S and variety on growth, yield and quality of irrigated linseed (Linumusitatissimum L.). Indian Journal of Agricultural Sciences, 83(4): 456-458

Singh, P. K., Husain, K., Tripathi, U. K., Malik, Y. P., Dubey, S. D., Singh, A. and Chandra, R. (2015). Linseed: Technology for increasing production (fifth edition), Project coordinating unit (Linseed), CSAU\&T, Kanpur. 